\title{
CO-CREATING AN ICT ARTEFACT WITH WOMEN IN SOUTH AFRICA
}

\author{
Ronel Smith ${ }^{1,2}$, Marita Turpin ${ }^{2}$ and Marlien Herselman ${ }^{1}$ \\ ${ }^{1}$ CSIR, Meraka, P.O. Box 395, Pretoria, South Africa \\ ${ }^{2}$ Department of Informatics, University of Pretoria, Private Bag X20, Hatfield, Pretoria, South Africa
}

\begin{abstract}
The active involvement of rural women in ICT4D initiatives is essential to ensure that they benefit from the initiative in general, and the technology artefact in particular. Usually ICT4D projects are male centered and the relevance of ICTs to the women within their contextual realities are not always considered. The purpose of this paper is indicate how an ICT artefact was co-created with rural women in South Africa in a resource constrained context. Participatory approaches like co-creation are important when implementing ICT4D initiatives aimed at rural women. Through the application of Design Science Research as the methodology an ICT artefact was co-created in a specific context in South Africa with rural women only. It is a longitudinal study that is still evolving. The lessons learnt and process that was followed will be shared. The main finding was that the active participation and feedback of the users of a system are essential when aiming to address their immediate and long term needs. If this is not the case the ICT artefact will not be used and it will yet again become part of the statistics of why Information Communication Technology for Development (ICT4D) projects fail.
\end{abstract}

\section{KEYWORDS}

Co-Creation, Rural Women, ICT4D, Design Science Research Methodology

\section{INTRODUCTION}

When conducting technology-based projects in rural communities in developing countries it is important to remember that ICTs are socio-technical systems(Moens, Broerse, Gast \& Bunders, 2010; Stillman, 2010). Western culture, typically unsuited to local requirements, is embedded in the design of technology, and when projects are ICT vendor or donor driven, this culture must be adapted to fit the community (Moens et al., 2010; Morales-Gomez \& Melesse, 1998). For ICT4D projects to be successful, context specific requirements and interpretations must be taken into account during the design process, with local community members afforded the opportunity to articulate their requirements, needs and demands (InfoDev, 2003). To maximise the value of co-creation, and avoid a top-down technology push, a bottom-up approach embedded in community participation is vital (David, Sabiescu \& Cantoni, 2013). Co-creation or a participatory approach allows for the incorporation of the social values, perspectives and knowledge of the communities thereby producing a product or solution, which bridges Heeks' design-reality gap (Khumalo \& Pather, 2018; Heeks, 2008; Puri, 2007). All this being said, community participation in an ICT4D context is always more complex than what has been reported in the literature ((Bailur in de la Harpe, 2014)), and even experienced ICT4D researchers and practitioners can find themselves with 'burnt fingers'. If ICT is exploited (like cultural capital), it can influence the way people will use technology as well as the value they give to the use of the ICT. This is even more the case in rural areas (Singh, Díaz Andrade \& Techatassanasoontorn, 2018).

The label of co-creation has been associated with various topics like developing new services, collaborating with users and innovators, adapting a product to the needs of users, participation of stakeholders in a community, creating new knowledge, networks and exchanging services (Ramaswamy \& Ozcan, 2018). Despite this diversity, however, there is surprisingly little consensus on what "co-creation" is. The research question that will be addressed in this study is: How can rural women benefit from a co-creation process that addresses their requirements and needs with relation to an ICT artefact? 


\section{CONCEPTUALISING CO-CREATION}

The term 'co-creation', which has its origin in the innovation domain, is increasingly being used in the development context along with terms such as 'user-driven innovation', 'co-production' and 'collaborative innovation' to describe the intended beneficiaries' involvement in the design of solutions that are relevant to their needs (Smith, 2015). Co-creation refers to a situation in which research participants collaborate with the research team in order to add value to the research process and to create something of value (Humphreys \& Grayson, 2008).

Co-creation can take place when the researcher and research participants are in contact with one another for a specific reason and/or to achieve a specific result. This contact creates the opportunity for the parties to influence each other's thinking and processes. Interaction must be mutual and reciprocal and should generally be beneficial for both parties, resulting in shared value creation (Grönroos, 2011; Windisch, 2011). Co-creation enables and empowers research participants to interact and collaborate with the researcher in order to create an artefact that has value for both parties (Edvardsson, Tronvoll \& Gruber, 2011). The production of the co-created artefact can be viewed as the generation of potential value, whereas use of the artefact is viewed as generation of real value (Grönroos, 2011).

Many papers apply the term "value co-creation" but do not define "co-creation", and then add the term "value". Attention is then distracted from "creation (Vargo \& Lusch, 2016). This resulted in comparing "co-production" and "value-in-use". Ranjan and Read Ranjan and Read (2016) have found that of the 149 papers they investigated, 71 papers focus on "co-production" and only 46 addressed "value-in-use". A focus on "value co-creation" was only indicated in 32 papers.

After investigating all concepts relating to co-creation Ramaswamy and Ozcan (2018:200) provides the best definition for co-creation pertaining to this study:

"Co-Creation is the enactment of interactional creation across interactive system-environments (afforded by interactive platforms), entailing agencing engagements and structuring organizations".

Ramaswamy and Ozcan Ramaswamy and Ozcan (2018) postulate that the real value of creation does not only apply to co-creating artefacts but rather lies with the value that the new co-designed artefact can have for them within their own contexts based on their involvement in their own networks. This is particularly relevant for this study as the rural women co-create an ICT artefact based on their needs and they get value out of this co-creation process as it improves the quality of their lives.

Ramaswamy and Ozcan (2018) also highlight the relation between co-creation and Giddens' structuration theory Giddens (1984), when they note the concepts of human agency and structure in their definition above. They also indicate that the test is to understand the role of both structure and agency and that these two concepts should not be juxtaposed but the value of both should be recognised as the interplay between them takes place. The idea is that agency and structure constitute responses that shape their orientations towards their contexts. This is also supported by Booyens, Hart and Ramoroka (2018) when they indicate that in South Africa agency has a role to play in innovation in developing contexts but that the involvement of the government is not very prominent to promote this. That is why some ICT4D studies do not acknowledge the innovation that takes place at an individual level as they develop products that are rooted in specific sociocultural contexts (Jiménez \& Zheng, 2018). In South Africa this is a challenge as the National Innovation System has to involve local communities when innovating (Booyens et al., 2018).

As one collaborates during co-creation, people from various levels in society join one another to share their visions, in the quest to co-design and co-implement refined products and services that focus on deprived communities' needs (Ranjan \& Read, 2016). This can ensue in socio-economic prosperity and a specific challenge in a community is addressed (Ruhl, Richter, Lembke \& Allert, 2014). Therefore Hood (Hood, 2018) argues that when we scale we consider not only to identify the right innovation to implement, but also how best to adapt it to individual contexts. Fundamental to this work are two components: (1) the robust deployment of continuous improvement methods to promote iterative innovation, and sustained learning and progress; (2) and a systemic approach to collaboration through the creation of powerful and well-designed networks.

Traditionally ICT4D research focuses on women as users and beneficiaries, not as co-creators. In response the World Bank (2009:3) emphasise the importance of involving women in projects by stating that various studies have "highlighted the need to ensure greater continuity between design and implementation to integrate women more fully into mainstream development activities". This is further supported by Jagtap and 
Larsson (2018) when they indicate that women living in poverty suffer many problems as compared to men living in poverty, as women have different needs and perspectives on problems they encounter. This implies that design research in this field can benefit from developing gender sensitive co-design approaches. This can result in more involvement of women in co-design activities.

\section{MODELS OF CO-CREATION TO CONSIDER}

In some community-based models of co-creation, a central issue is the lack of power of community members who are involved. This is found especially when co-designing with technology, as well as in value co-creation. In each case, there are inherent power differentials, and this should be carefully managed in order to allow all involved to participate meaningfully in the co-creation process (Greenhalgh, Jackson, Shaw \& Janamian, 2016). Value also lies in empowerment especially when you develop an artefact during collaboration as the participant's motivation and ambitions are enhanced (Novani, Putro \& Hermawan, 2015).

Various models of co-creation exist (Edvardsson et al., 2011; Andreu, Sánchez \& Mele, 2010; Gebauer, Johnson \& Enquist, 2010; Zwass, 2010; Payne, Storbacka \& Frow, 2008; Zwick, Bonsu \& Darmody, 2008; Prahalad \& Ramaswamy, 2004), but according to Durugbo and Pawar (2014) and supported by Ramaswamy and Ozcan (2018) most of these focus on the dynamics between a supplier, customer and encounter domains during the co-creation process. Value is derived from value in exchange as well as value in use. Durugbo and Pawar (2014), however developed a unified model of co-creation (Figure 1) and they explicitly define the key role of existing value and technique selection during co-creation (unlike other studies on co-creation). This research proposes a 'unified model' when you formalise the process in co-creation.

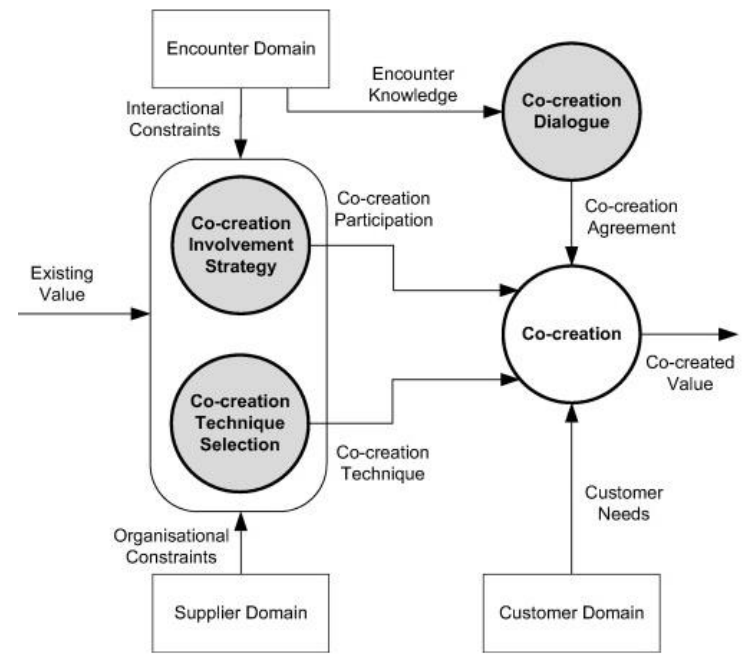

Figure 1. A Model for co-creation (Durugbo \& Pawar, 2014)

This model adds a new perspective on collaboration during co-creation and it includes themes like capability-, customer-, governance-, intelligence-, value-, role-, process-, service-, and community-focused. This model has particular reference to this study as co-creation within a specific community is all about dialogue, participation, knowledge sharing, sense making, needs and to create value to the community in the end, in use and in their context.

Various authors (De Koning, Crul \& Wever, 2016; Putro, 2016; Novani et al., 2015; Kijima, Rintamki \& Mitronen, 2012) indicate that a co-creation process should include specific steps like identify, analyse, define, design, realize and evaluate or listen, identify, ideate, collaborate, evaluate and experiment. However, according to Kijima et al. (2012) and supported by Suryana, Mayangsari and Novani (2017), for co-creation to have real value your co-creation process steps should rather be: co-experience, co-definition, co-elevation, and co-development. When applying co-experience, the client and supplier should share their understanding of the nature of the problem, process and to comprehend each other's preferences, capabilities, and expectations so that they may co-define and share a common internal model (Putro, 2016). Co-elevation has 
to do with the process of understanding the expectations of customers and abilities of the providers. The higher the expectation the greater the value. Thus, co-development addresses co-innovation that is the result of people who collaborate (Novani et al., 2015).

True participatory design is more than just getting the users involved in the 'how' of implementation. They should also be involved in setting the agenda and deciding on the approach (Moens et al., 2010). Full and active participation of the end users and local community in the design of an ICT artefact is crucial to ensure its usefulness at local level by directly addressing local needs, as well as promoting buy-in and the development of local champions (Booyens et al., 2018; David et al., 2013; Gurnstein, 2003).

\section{THE ICT ARTEFACT}

The ICT artefact in this paper stems from a project coined the Digital Doorway that has been in existence since 2002 and was developed with the main purpose of promoting digital literacy skills in deep rural areas. It has adapted the idea of 'The Hole in the Wall project' from India(Gush, 2018).

At the time of writing, sites are deployed throughout the nine provinces of South Africa and consist of 60 weatherproof walk-in containers with a built-in solar panel. To date more than 300 units have been deployed throughout South Africa, mostly in deep rural settlements. Internationally 30 Digital Doorways have been deployed in Uganda, four in Australia and one each in Lesotho, Ethiopia, and the Solomon Islands. The Digital Drum, a Digital Doorway in a 20 gallon drum developed with UNICEF for use in Uganda, was nominated by the Time Magazine as one of the top 50 inventions in the world for 2011 (Smith \& Turpin, 2017). Most of the sites support VSAT Internet connectivity enabling them to transmit near-real-time data (comprised of many parameters) back to a monitoring server and support desk. There is thus a large amount of raw data on the who uses the machines and for what purposes available (Gush, 2018).

The current DDs include a satellite downlink and GPRS backhaul to access content and to log file retrieval. A Bluetooth dongle and GUI application allow a user to save files from the DD to a personal device. A user can create a personal account and enter their information (age, gender, home language). This data, as well as specific application usage is hosted on a server. A webcam allows users to create a personalised profile and they receive incentives for logins. This ensures the validation of demographic data. The system is based on Open source software, employing a modified Ubuntu Linux OS with the Xfce display. The Linux security mechanisms prevent unauthorised modification to essential folders and files (Gush, 2018).

The DD was selected as ICT artefact for this research project because it has proven itself to be very reliable and uniquely suited to the harsh environment of the rural areas in which the project will be conducted. The researcher's on-going involvement with the DD was useful when hardware and software modifications based on the middle-aged women's feedback needed to be made.

The DD was first installed at the Setsong Community Centre in August 2013, in a community consisting mostly of rural women over the age of 64 years. Currently the Setsong Centre is a place where the older women gather to work on projects such as sewing, beadwork, reed work (e.g. making brooms and baskets) and farming on a communal farm. The ICT artefact was co-created by through 7 site visits ( $c f$ Table 1$)$ and refining the artefact based on feedback from the women and by applying the co-creation model as well as processes described in section 3 of this paper.

\section{RESEARCH METHODOLOGY}

A pragmatist research philosophy is adopted. Pragmatists are concerned with solutions to problems that work, and knowledge is viewed as a way to improve the world (Cresswell \& Sheikh, 2013). This view aligns well with the Design Science Research (DSR) aim of changing the current situation into a desired one (Goldkuhl, 2012). In fact, some authors contend that DSR is essentially pragmatic in nature (Hevner, 2007).

The reason for choosing Design Science as a research methodology was to co-create the ICT artefact with the rural women by applying the specific DSR process of Peffers(Peffers, Tuunanen, Rothenberger \& Chatterjee, 2007) (Figure 2).

DSR is used as the research strategy. DSR is a creative problem solving methodology that focuses on the production of innovative and new knowledge in order to solve a problem. DSR researchers are concerned with relevance and making an impact(Baskerville, Baiyere, Gregor, Hevner \& Rossi, 2018). 


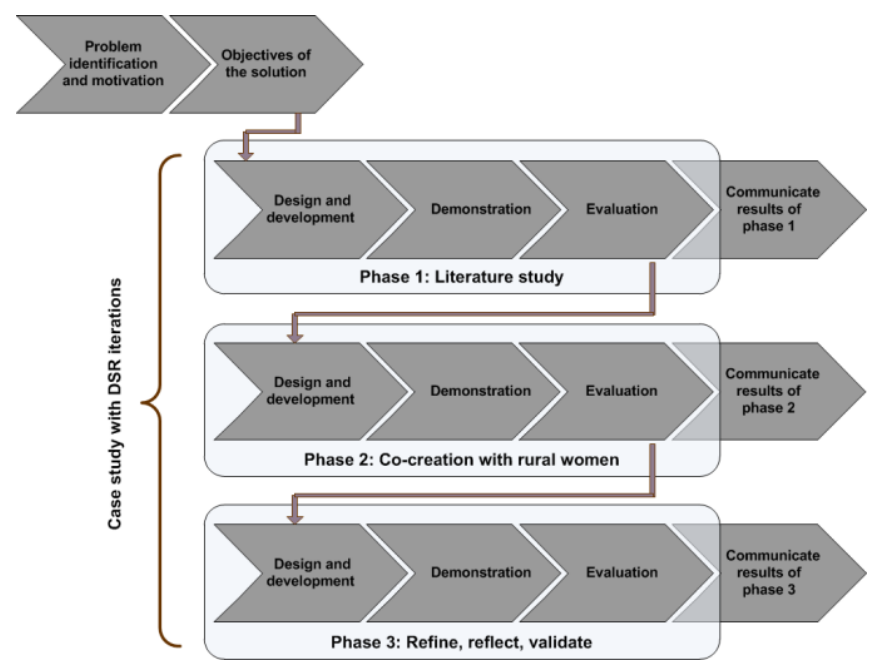

Figure 2. Design Science Research Methodology as applied in this study (Adapted from (Peffers et al., 2007) and (Herselman \& Botha, 2014))

The focus of this paper is on Phase 2 of the process where the ICT artefact was designed, developed and demonstrated as well as evaluated to improve it, by the rural women in Limpopo Province of South Africa.

\section{RESULTS AND DISCUSSIONS}

The ICT artefact was co-created during 7 site visits ranging from April 2013 to October 2016. Visit 7 constituted an assessment and the building of a new site for the ICT artefact in order for the project to continue, since the building where it was hosted was severely damaged by a storm. The project is still in progress at the time of writing. The design activities that occurred during the site visits are summarized in Table 1. Note that 'RURAL WOMEN' is an abbreviation of 'Elderly Rural Women', the participant group for the co-design study.

Table 1. Design Activities during Co-creation of ICT Platform

\begin{tabular}{|c|c|c|c|c|}
\hline $\begin{array}{l}\text { RURAL WOMEN } \\
\text { design activities }\end{array}$ & RURAL WOMEN activities & $\begin{array}{l}\text { Site } \\
\text { visit \# }\end{array}$ & CSIR team activities & $\begin{array}{l}\text { CSIR team } \\
\text { design activities }\end{array}$ \\
\hline Listen & $\begin{array}{l}\text { Mma C (leader of the rural } \\
\text { women) agrees to participate } \\
\text { and involves the other } 21 \text { rural } \\
\text { women }\end{array}$ & Prior & $\begin{array}{l}\text { Prior learning from rural DD projects } \\
\text { Identify need for RURAL WOMEN } \\
\text { study } \\
\text { Identify Mafarafara site } \\
\text { Establish relationship with Mma C }\end{array}$ & Identify \\
\hline $\begin{array}{l}\text { Listen } \\
\text { Evaluate }\end{array}$ & $\begin{array}{l}\text { Rural women share contextual } \\
\text { information and evaluate } \\
\text { desirability of the project }\end{array}$ & 1 & $\begin{array}{l}\text { Introduce project } \\
\text { Obtain ethical consent }\end{array}$ & $\begin{array}{l}\text { Listen } \\
\text { Ideate }\end{array}$ \\
\hline & & $1 \mathrm{a}$ & Pre-installation site inspection & Identify \\
\hline Collaborate & Help install ICT artefact & 2 & Install ICT platform & Collaborate \\
\hline Experiment & $\begin{array}{l}\text { Participate in training and share } \\
\text { information on livelihoods }\end{array}$ & & $\begin{array}{l}\text { Give training } \\
\text { Interview RURAL WOMEN on } \\
\text { livelihoods } \\
\text { First update of ICT platform }\end{array}$ & Listen \\
\hline $\begin{array}{l}\text { Collaborate } \\
\text { Experiment } \\
\text { Identify }\end{array}$ & $\begin{array}{l}\text { Assist each other with use } \\
\text { Maintain and clean venue } \\
\text { Share info on use and further } \\
\text { needs }\end{array}$ & 3 & $\begin{array}{l}\text { Assess use of ICT platform } \\
\text { Identify further needs }\end{array}$ & $\begin{array}{l}\text { Evaluate } \\
\text { Listen } \\
\text { Identify }\end{array}$ \\
\hline & & $3 a$ & $\begin{array}{l}\text { Upgrade solar panels } \\
\text { Update information base }\end{array}$ & \\
\hline $\begin{array}{l}\text { Collaborate } \\
\text { Experiment }\end{array}$ & $\begin{array}{l}\text { Share use experiences and info } \\
\text { on further needs }\end{array}$ & 4 & $\begin{array}{l}\text { Evaluate use of ICT artefact } \\
\text { Identify further needs }\end{array}$ & $\begin{array}{l}\text { Evaluate } \\
\text { Listen }\end{array}$ \\
\hline
\end{tabular}




\begin{tabular}{|c|c|c|c|c|}
\hline $\begin{array}{l}\text { RURAL WOMEN } \\
\text { design activities }\end{array}$ & RURAL WOMEN activities & $\begin{array}{l}\text { Site } \\
\text { visit \# }\end{array}$ & CSIR team activities & $\begin{array}{l}\text { CSIR team } \\
\text { design activities }\end{array}$ \\
\hline \multirow{5}{*}{$\begin{array}{l}\text { Identify } \\
\text { Collaborate } \\
\text { Experiment } \\
\text { Identify }\end{array}$} & Assist each other with use & & & Identify \\
\hline & \multirow{4}{*}{$\begin{array}{l}\text { Share use experiences and info } \\
\text { on further needs } \\
\text { Assist each other with use }\end{array}$} & \multirow[t]{3}{*}{5} & \multirow{3}{*}{$\begin{array}{l}\text { Evaluate use of ICT artefact } \\
\text { Identify further needs }\end{array}$} & Evaluate \\
\hline & & & & Listen \\
\hline & & & & Identify \\
\hline & & $5 \mathrm{a}$ & $\begin{array}{l}\text { Remove ICT artefact for } \\
\text { maintenance and updates }\end{array}$ & \\
\hline Collaborate & Share enthusiasm for returned & 6 & Re-install ICT artefact & Evaluate \\
\hline Experiment & ICT artefact & & Install new printer & \\
\hline \multirow[t]{2}{*}{ Define } & $\begin{array}{l}\text { Use updated ICT artefact and } \\
\text { give feedback }\end{array}$ & & & \\
\hline & $\begin{array}{l}\text { Plan to upgrade Community } \\
\text { center and lapa }\end{array}$ & & & \\
\hline \multirow[t]{3}{*}{ Collaborate } & Share plans and activities & 7 & \multirow{3}{*}{$\begin{array}{l}\text { Assess storm damage } \\
\text { Arrange temporary safekeeping of } \\
\text { ICT artefact }\end{array}$} & Listen \\
\hline & towards new building & & & Identify \\
\hline & Progression with new building & After & & \\
\hline
\end{tabular}

From site visits 3 to 5, there is a lot of repetition of activities: continued use of the ICT artefact on the rural women's side, and continued evaluation and further needs assessment on the CSIR's side. As time progressed and the rural women became familiar with the ICT artefact, they could provide more informed inputs related to further needs.

The CSIR team installed existing technology that was refined with and for the rural women who had unique user needs, in the process. As such, their design activities consisted mainly of evaluating use, listening to the users and identifying further needs. Because it was an existing product, not much ideation needed to happen.

The rural women's main activities consisted of trying out the technology that was totally new to them, thus they were experimenting. Throughout the project they did so in a collaborative manner, assisting each other to use the ICT artefact. Their use of the ICT artefact became integrated with their other collaborative activities at the community centre, such as sewing and weaving. Their continued use of the ICT artefact enabled them to better identify additional needs related to the information base and use of the ICT artefact.

\section{UNEXPECTED FINDINGS}

The women's feedback on the benefits of the ICT platform held some surprises. The first one was the pride that especially the illiterate rural women took in being able to type their name (their login username was their own name). The illiterate rural women could not use the ICT platform extensively, but they could perform some tasks such as playing games and watching videos. One of them reported that the training on the ICT platform enabled her to use an ATM for the first time in her life; previously she always required someone else to do her ATM banking for her. Activities such as these were a major accomplishment for some of the rural women that believed they were too old to learn, and would never be able to use computers because of being illiterate.

A second surprise was the pleasure they derived from playing games, many of which were educational. They did not only enjoy the games but believed that the games took away their stress as it made them forget about their worries. This is a major benefit to people who are in survivalist mode and who are regularly stressing about the next meal and other basic livelihood concerns.

There was a further unexpected benefit the rural women shared during feedback sessions, of exercising their bodies and fingers when moving between screens and having to type on the keyboard.

Lastly, from the interview data and site visit reports it became clear that visiting the community centre on a regular basis to use the ICT platform gave especially the retired women a sense of purpose.

The unexpected benefits were in a sense unique to the rural women: as a group they had high levels of illiteracy, a number of survivalist stresses and concerns, the retired person's loss of sense of purpose to their life, and age related ailments such as arthritis. Hence, the ICT platform project could be said to benefit the rural women in a unique manner, due to their unique composition but also due to the success of the project, without which they would not have adopted and regularly used the ICT platform. 


\section{CONCLUSION}

ICT4D strategies and initiatives aimed at improving the situation rural women find themselves in, must place more emphasis on local realities such as power structures and indigenous sources of knowledge than has been done to date. For the women to benefit from 'new' knowledge such as that gained from ICTs, it must be integrated with their local knowledge within the context they are intimately familiar with. To make new technologies work for, rather than against women in rural areas it is important to take into consideration that they have different needs, capacities and skills than men. Consulting women when co-designing and co-creating with ICT is essential as this can empower them towards capacity building. Specific steps in the process of co-creation during the design process are crucial to follow as well as a specific co-creation model. Soliciting the views of RURAL WOMEN on new technology and involving them in the design can make the development of the technology more user-oriented and will improve the likelihood that they will adopt it.

\section{ACKNOWLEDGEMENT}

This paper acknowledges the support of the CSIR in South Africa for using the Digital Doorway project for the purpose of co-creation with rural women, the Department of Science and Technology for their funding and the University of Pretoria for supporting the project through research.

\section{REFERENCES}

Andreu, L., Sánchez, I. \& Mele, C. 2010. Value co-creation among retailers and consumers: New insights into the furniture market. Journal of Retailing and Consumer Services, 17(4):241-250.

Baskerville, R., Baiyere, A., Gregor, S., Hevner, A. \& Rossi, M. 2018. Design Science Research Contributions: Finding a Balance between Artifact and Theory. Journal of the Association for Information Systems, 19(5):358-376.

Booyens, I., Hart, T.G. \& Ramoroka, K.H. 2018. Local innovation networking dynamics: evidence from South Africa. The European Journal of Development Research, 30(4):749-767.

Cresswell, K. \& Sheikh, A. 2013. Organizational issues in the implementation and adoption of health information technology innovations: An interpretative review. International Journal of Medical Informatics, 82(5):e73-e86.

David, S., Sabiescu, A.G. \& Cantoni, L. 2013. Co-design with Communities. A Reflection on the Literature Public and private access to ICTs in developing regions. Proceedings of the 7th International Development Informatics Association Conference, 1-3 November. Bangkok, Thailand.

De Koning, J.I., Crul, M.R. \& Wever, R. 2016. Models of co-creation. Service Design Geographies. Proceedings of the ServDes. 2016 Conference.

de la Harpe, R. 2014. The level of participation during the development of a mobile application for home-based healthcare data in a developing context: An actor-network theory perspective. SACJ, 54:20-33.

Durugbo, C. \& Pawar, K. 2014. A unified model of the co-creation process. Expert Systems with Applications, 41(9):4373-4387.

Edvardsson, B., Tronvoll, B. \& Gruber, T. 2011. Expanding understanding of service exchange and value co-creation: a social construction approach. Journal of the Acadamy of Marketing science, 39:327-339.

Gebauer, H., Johnson, M. \& Enquist, B. 2010. Value co-creation as a determinant of success in public transport services: A study of the Swiss Federal Railway operator (SBB). Managing Service Quality: An International Journal, 20(6):511-530.

Giddens, A. 1984. The constitution of society : outline of the theory of structuration. Berkeley: University of California Press.

Goldkuhl, G. 2012. Pragmatism vs interpretivism in qualitative information systems research. European Journal of Information Systems, 21(2):135 - 146.

Greenhalgh, T., Jackson, C., Shaw, S. \& Janamian, T. 2016. Achieving research impact through co-creation in community-based health services: literature review and case study. The Milbank Quarterly, 94(2):392-429.

Grönroos, C. 2011. Value co-creation in service logic: a critical analysis. Marketing theory, 11(3):279-301.

Gurnstein, M. 2003. Effective use: a community informatics strategy beyond the digital divide. First Monday, 8(12):1 - 14.

Gush, K. 2018. An open-source tool-set for meaningful monitoring and visualisation of rural ICT projects. 2018 IST-Africa Week Conference (IST-Africa).

Heeks, R. 2008. ICT4D 2.0: The next phase of applying ICT for international development. Computer, 41(6):26-33. 
Herselman, M. \& Botha, A. 2014. Designing and implementing an Information Communication Technology for Rural Education Development (ICT4RED) initiative in a resource constraint environment: Nciba school district, Eastern Cape, South Africa. Pretoria, South Africa: CSIR.

Hevner, A.R. 2007. A three cycle view of design science research. Scandinavian Journal of Information Systems, 19(2):4.

Hood, N. 2018. The quest for scale: Achieving system-wide innovation and improvement in education.

Humphreys, A. \& Grayson, K. 2008. The intersecting roles of consumer and producer: a critical perspective on co-production, co-creation and prosumption. Sociology compass, 2(3):963-980.

InfoDev 2003. ICT for Development. Contributing to the Millenium Development Goals: Lessons learnt from seventeen InfoDev projects. Washington DC, USA: InfoDev.

Jagtap, S. \& Larsson, T. 2018. Design and Frugal Innovations: Three roles of resource-poor people. Design 2018.

Jiménez, A. \& Zheng, Y. 2018. Tech hubs, innovation and development. Information Technology for Development, 24(1):95-118.

Khumalo, C. \& Pather, S. 2018. Investigation of a Co-Design Approach for a Civic Engagement Mobile Application. 2018 IST-Africa Week Conference (IST-Africa).

Kijima, K., Rintamki, T. \& Mitronen, L. 2012. Value orchestration platform: model and strategies. Advances in the Human Side of Service Engineering:433.

Moens, N.P., Broerse, J.E.W., Gast, L. \& Bunders, J.F.G. 2010. A Constructive Technology Assessment Approach to ICT Planning in Developing Countries: Evaluating the First Phase, the Roundtable Workshop. Information Technology for Development, 16(1):34.

Morales-Gomez, D. \& Melesse, M. 1998. Utilising information and communication technologies for development: The social dimensions. Information Technology for Development, 8(1):1-12.

Novani, S., Putro, U.S. \& Hermawan, P. 2015. Value orchestration platform: promoting tourism in batik industrial cluster solo. Procedia-Social and Behavioral Sciences, 169:207-216.

Payne, A.F., Storbacka, K. \& Frow, P. 2008. Managing the co-creation of value. Journal of the Academy of Marketing Science, 36(1):83-96.

Peffers, K., Tuunanen, T., Rothenberger, M.A. \& Chatterjee, S. 2007. A design science research methodology for information systems research. Journal of management information systems, 24(3):45 - 77.

Prahalad, C.K. \& Ramaswamy, V. 2004. Co-creation experiences: The next practice in value creation. Journal of interactive marketing, 18(3):5-14.

Puri, S.K. 2007. Integrating scientific with indigenous knowledge: constructing knowledge alliances for land management in India. MIS Quarterly, 31(2):355 - 379.

Putro, U.S. 2016. Value Co-creation Platform as Part of an Integrative Group Model-Building Process in Policy Development in Indonesia. Systems Science for Complex Policy Making. Springer.

Ramaswamy, V. \& Ozcan, K. 2018. What is co-creation? An interactional creation framework and its implications for value creation. Journal of Business Research, 84:196-205.

Ranjan, K.R. \& Read, S. 2016. Value co-creation: concept and measurement. Journal of the Academy of Marketing Science, 44(3):290-315.

Ruhl, E., Richter, C., Lembke, J. \& Allert, H. 2014. Beyond methods: Co-creation from a practice-oriented perspective. Proceedings of Design Research Society Biennial International Conference, Umeå, Sweden.

Singh, H., Díaz Andrade, A. \& Techatassanasoontorn, A.A. 2018. The practice of ICT-enabled development. Information Technology for Development, 24(1):37-62.

Smith, R. 2015. Women, participation and design in ICT4D: Addressing barriers using a co-creation approach.

Smith, R. \& Turpin, M. 2017. Design Science Research and Activity Theory in ICT4D: Developing a Socially Relevant ICT Platform for Elderly Women in Remote Rural South Africa. International Conference on Social Implications of Computers in Developing Countries.

Stillman, L. 2010. Technologies of care in community-based organisations: agency and autheticity. AI and Society, 25:309-320.

Suryana, L.A., Mayangsari, L. \& Novani, S. 2017. A Virtual Co-Creation Model Of The Hijab Fashion Industry In Indonesia. International Journal of Business \& Society, 18.

Vargo, S.L. \& Lusch, R.F. 2016. Institutions and axioms: an extension and update of service-dominant logic. Journal of the Academy of Marketing Science, 44(1):5-23.

Windisch, K. 2011. Co-Creation and the ethics of stakeholder engagement for value creation. Arhus University.

World Bank 2009. Information and Communications for Development: extending reach and increasing impact. Washington DC: World Bank.

Zwass, V. 2010. Co-creation: Toward a taxonomy and an integrated research perspective. International journal of electronic commerce, 15(1):11-48.

Zwick, D., Bonsu, S.K. \& Darmody, A. 2008. Putting Consumers to Work: Co-creationand new marketing governmentality. Journal of consumer culture, 8(2):163-196. 